\title{
EU and Mercosur vis a vis the Trade Agreement. Remarks from the institutional perspective
}

Isabella Querci*

\section{ABSTRACT}

The member States of Mercosur are currently negotiating a Trade Agreement with the EU, as part of the process towards a comprehensive bi-regional Association Agreement. In 2016, the EU and Mercosur members exchanged offers, followed by a negotiation round. The next round will be held in October 2017; while awaiting for political developments, it is worth anticipating some challenges to come, especially from a legal perspective. Both actors have a multilayered system for decision-making, requiring the consensus of a multiplicity of governmental actors and thus enabling them to convey. Furthermore, current dialogues consider a broad range of issues, which were also covered by different EU's agreements with other trading partners. These agreements received critiques from the civil society, which are worth to reflect upon, considering that the trade agreement is due to impact the general negotiation for the bi-regional Association Agreement. The paper develops this reflection from a twofold perspective: that of the institutional nature of EU and Mercosur and that of the democratic deficit in the overall negotiation process.

Key words: European Union, Mercosur, trade agreement, institutions, wTO, statehood, civil society.

Doctor in International and European Union Law, at Università degli Studi di Genova, Italy. International Relations Officer - EU Project Manager presso. Università degli Studi di Genova, (Italia). [Isabella.querci@unige.it].

My greatest gratitude goes to the colleague and friend Dr. Carlos Alberto Chichilla Imbett, hoping that this project will be the first of many others to come. Every error remains my own.

Recibido: 20 de marzo de 2017 / Modificado: 4 de agosto de 2017 / Aceptado: 14 de septiembre de 2017

Para citar este artículo:

Querci, I. (2017). EU and Mercosur vis a vis the Trade Agreement. Remarks from the institutional perspective. OASIS, 26, 63-80.

Dor: https://doi.org/10.18601/16577558.n26.05 


\section{Unión Europea y Mercosur vis a vis el Tratado de Comercio. Observaciones desde la perspectiva institucional}

\section{RESUMEN}

Los Estados miembros de Mercosur están actualmente negociando un acuerdo comercial con la Unión Europea, como parte del proceso hacia la integración comercial birregional. En 2016, la Unión Europea y el Mercosur intercambiaron ofertas, luego de unas rondas de negociación. La siguiente cita es en 2017, mientras que se esperan algunos cambios políticos, en especial, desde la perspectiva legal. Además, ambos actores tienen que agotar un número de etapas para la toma de decisiones, entre las cuales se encuentra el consenso de los actores gubernamentales y la determinación de sus competencias. Ahora, los diálogos actuales requieren resolver una amplia gama de cuestiones que estaban ya debatidas por distintos acuerdos firmados por la Unión Europea con otros socios comerciales. Tales acuerdos deberían ser tenidos en cuenta en el proceso de negociación entre la Unión Europea y Mercosur. El presente artículo desarrolla esta última reflexión desde dos puntos de vista: por una parte, el carácter institucional de la Unión Europea y el Mercosur; por otra, el déficit democrático en el proceso general de negociación entre los actores.

Palabras clave: Unión Europea, Mercosur, acuerdo comercial, instituciones, omc, Estado, sociedad civil.

\section{THE EU - MERCOSUR INSTITUTIONAL RELATIONSHIP IN TRADE}

Since 1995, Mercosur-EU relations have been guided by the Framework Cooperation Agreement, signed on 15 December 1995 and fully in force as of 1 July $1999^{1}$. In addition, some individual Mercosur countries (more specifically, Paraguay ${ }^{2}$ Uruguay $^{3}$ and Argentina ${ }^{4}$ ) have in place bilateral Framework Cooperation Agreements with the EU, which also establish a structure for dealing with traderelated matters.

The objective of these instruments was to create a framework for negotiations on an

1 Interregional Framework Cooperation Agreement between the European Community and its Member States, of the one part, and the Southern Common Market and its Party States, of the other part. Signed on December $15^{\text {th }}$, 1995 and entered into force on July $1^{\text {st }} 1999$. OJ L69, 19/03/1996, p. 4.

2 Framework Agreement for cooperation between the European Economic Community and the Republic of Paraguay, entered into force on $30^{\text {th }}$ October 1992.

3 Framework Agreement for cooperation between the European Economic Community and the Eastern Republic of Uruguay - Exchange of Letters Signed on November the $4^{\text {th }} 1991$ and entered into force on January $1^{\text {st }} 1994$. OJ L94, 08/04/1992, p. 2.

4 Framework Agreement for trade and economic cooperation between the European Economic Community and the Argentine Republic - Exchange of Letters, OJ L 295, 26.10.1990, p. 67-73. 
Interregional Association Agreement, which would ideally include full liberalization of trade in goods and services in conformity with wTO rules, enhanced forms of co-operation and strengthened political dialogue between Mercosur and the EU. More specifically, negotiators identified a dynamic strategy divided into two stages in order to achieve the conclusion of the Interregional Association Agreement. The first stage involves the conclusion of an Interregional Framework Agreement on trade and economic cooperation that would cover trade liberalization, support for the integration of Mercosur, enhancing dialogue and consultations between the parties at ministerial level on policy and cooperation issues of common interest. The second stage instead involves the creation of an interregional association between the European Union and Mercosur, which is the long-term objective of the overall negotiation. The association would ideally be based on a balanced and mutual partnership at political, economic and commercial level. It should be aimed at promoting an increase in interregional trade of mutual benefit, increasing investment for foreign companies, strengthening political cooperation at international level, in particular by adopting common positions in international bodies on issues of mutual interest. In other words, the central aspects of the association would be the liberalization of trade, services and capital, embedded in a wider framework of political and institutional coordination within (but not limited to) international fora. These being the goals currently pursued at the high policy level, the reality is instead rather less ambitious.

As a matter of definitions, in EU's legal lexicon, an Interregional Association Agreement (IAA) is an "international agreement that the EU has concluded with third [...] blocs (of States) with the aim of setting up an all-embracing framework to conduct bilateral relations". Differently, a Free Trade Agreement (FTA) is an "agreement in which both parties agree to trade freely with one another without imposing tariffs" (European Union External Action Service, 2011). The scope of an IAA is therefore much wider than an FTA's. In such a framework, it is possible that a "trade chapter" of an IAA transforms in an autonomous FTA (and vice versa an FTA is converted in a chapter of an IAA) according to the smoothness of negotiations in one field or another.

The Mercosur countries form a free trade area and an increasingly integrated market of 250 million consumers 5 . They also generate together the fifth largest GDP in the world. In

5 For the four Mercosur countries negotiating with the EU, the EU is Mercosur's first trading partner, accounting for $21 \%$ of the bloc's total trade in 2015 . The EU's exports to the region have increased from $€ 21$ billion in 2005 to $€ 46$ billion in 2015. Mercosur's exports have increased from $€ 32$ billion to $€ 42$ billion over the same period. Mercosur's biggest exports to the EU in 2015 were agricultural products, such as foodstuffs, beverages and tobacco (24\%), vegetable products including soya and coffee $(18 \%)$ and meats and other animal products $(6 \%)$. Other exports include mineral products $(14 \%)$, wood and paper products $(8 \%)$ and machinery $(5 \%)$. The EU's exports to Mercosur include machinery (29\%), vehicles and parts (17\% of total exports) and chemicals and pharmaceuticals (24\%). The $\mathrm{EU}$ is also a major exporter of commercial services to Mercosur ( $€ 20$ billion in 2014). The EU is the biggest foreign 
2015, Mercosur was the tenth largest export market for the EU goods ${ }^{6}$. Mercosur and the EU began negotiations in order to put in place one of the building blocks of the IAA in April 2000. In September 2004, both parties made available their market access offers. From that moment, several institutional and informal meetings and a prolonged stagnation took place $^{7}$, up to May 2016, when negotiators met in Brussels to develop their offers on access to their respective markets of goods, services and government procurement. After this exchange, the tenth round of negotiations concluded in Brussels on October 2016 and we are now awaiting for the next one, which is going to take place in Brasilia between 2 and 6 October $2017^{8}$. Three main principles govern the trade chapter negotiations (Hinojsa, 2009): i) a region-to-region (or bi-regional) approach, which constitutes the basis of discussions on all regulatory areas; ii) the agreement should be comprehensive and balanced, going beyond the respective obligations in WTO. No sector should be excluded, while taking account of product sensitivities; iii) the agreement should constitute a single undertaking, implemented by the parties as an indivisible whole.

While negotiations were ongoing, all Mercosur countries, with the exception of Paraguay, were de-listed from the EU's Generalized Scheme of Preferences (GSP), due to their classification as high middle-income countries. The GsP scheme is designed to allow developing countries to pay less or no duties

investor in the region, rising from $€ 130$ billion in 2000 to $€ 387$ billion in 2014 . Mercosur is a major investor in the EU, with stocks of $€ 115$ billion in 2014. Source: EU Commission, 2017.

6 Comprehensive Free Trade Agreement with Mercosur Potential gains for the EU May 2016, available at http:// trade.ec.europa.eu.

7 On 04 May 2010 the European Commission decided to relaunch trade negotiations with Mercosur. Following the re-launch, the first round of negotiations was held from 29 June to 02 July 2010 in Buenos Aires. The second round took place in Brussels on 11-15 October, and the third round in Brasilia from 22 November to 07 December 2010. In February 2011 in Paraguay and Uruguay, MERCOSUR and EU met to advance their ongoing trade negotiations. The following rounds of negotiations took place on 14-18 March 2011 in Brussels and on 02-06 May 2011 in Asunción, Paraguay. In In the context of the XXII Bi-Regional Negotiations Committee (BNC), delegations from MERCOSUR and the European Union held working meetings from July 4th to July 8th, 2011. The XXIII BiRegional Negotiations Committee (BNC), took place from 7 to 11 November 2011. The eight round was held in the context of the XXIV meeting of the Bi-Regional Negotiations Committee (BNC), from 12 to 16 March 2012. In the framework of the XXV Bi-regional Negotiations Committee, delegates from MERCOSUR and the European Union met in Brasília from 22 to 26 October 2012 for the ninth round of MERCOSUR-EU negotiations. Delegates from MERCOSUR and the European Union met for a Ministerial Meeting in Santiago, Chile, on January 26, 2013. On 24 February 2014, in the context of the Seventh Brazil-EU Summit, the Brazilian president indicates that a free trade deal between MERCOSUR and the EU is close to completion. On 11 June 2015, representatives from MERCOSUR and the European Union held a Ministerial Meeting in Brussels, Belgium.

8 The round should have taken place in March 2017, but was postponed. Yet, both blocs have made comments in recent weeks to the effect that a final deal will be announced in December 2017 at the World Trade Organisation's 11 th ministerial conference in Buenos Aires. 
on their exports to the EU, in order to give them access to EU markets and contribute to mutual economic growth. As from 1 January 2014, the EU's reformed GsP scheme focuses support on developing countries most in need ${ }^{9}$. Mercosur's member States remain today GSP-eligible countries, an option that they would lose in the moment in which an FTA (or a fortiori an IAA) enters into force, because the FTA is incompatible with the application of the GSP scheme. From a trade perspective, failure to reach an agreement with the EU means that Mercosur countries would have to compete with other exporting countries that benefit from GSP scheme as well as those that have already an FTA in place.

The exclusion of Mercosur's members from the GSP scheme, previously allowing the same States to access EU's market under privileged conditions, can represent a boost to negotiations. The conclusion of the FTA would somehow resume preferential conditions of trade between Mercosur's States and the EU. Over the last round, negotiators covered a wide array of topics, such trade in goods; rules of origin; customs and trade facilitation (including mutual administrative assistance and anti-fraud clause); technical barriers to trade; sanitary and phytosanitary measures; trade defense instruments; subsidies; dispute settlement; services and establishment; public procurement; intellectual property (including geographical indicators); competition and State-owned enterprises. Some of the chapters proved to be particularly contentious, as for instance the parts relating to dispute settlement mechanisms, public procurement and State-owned enterprise, due to the important reforms that their implementation imply in the very socio-economic structure of the relevant States. Overall, a trade agreement between the EU and Mercosur would help to reduce barriers to trade of any nature, allowing for a more fluid and efficient exchange of goods and services between the regions, since the reduction of tariffs remains the primary goal. The agreement would serve mainly to enhance preexisting ties and relations (such the Framework Cooperation Agreement of 1995) and provide for institutionalized forms of cooperation. The EU's trade strategy paper (EU Commission, 2015) identifies Mercosur as one of the priority areas for Europe's regional trade negotiations (Malmström, 2017), based on the size of the Mercosur market and the potential for stimulating inter-regional trade flows by removing market access obstacles ${ }^{10}$.

Given the scope of the negotiations' subject matter, it is impossible to cover it comprehensively herewith. The paper therefore explores some of the most challenging aspects of the agreement, assessing them against the backdrop of the advantages promised to both parties, bearing in mind that the FTA is due

9 Regulation (Eu) No 978/2012 of the European Parliament and of the Council of 25 October 2012 applying a scheme of generalised tariff preferences and repealing Council Regulation (EC) No 732/2008.

10 According to data from the European Commission, in 2016 the EU exported goods to the Mercosur countries worth $€ 43.2 \mathrm{bn}$ and imported $€ 41.6 \mathrm{bn}$. Source: Natalia Kidd, www.euractive.com. 
to impact on the overall negotiation for the IAA. The chosen aspects are, on the one hand, institutional (some would even say constitutional) (De Wet, 2006) nature of the EU and Mercosur and, on the other hand, the argument of the democratic deficit in negotiations. Both aspects have been selected because of their ability to encompass several other more specific critiques, which cannot be dealt with at the present stage of negotiations ${ }^{11}$.

In order to do so, the next section highlights some institutional aspects of the relevant actors and their treaty-making law and practice, as prerequisites for the analysis that follows.

\section{EU'S LAW AND PROCEDURE FOR AGREEMENTS' CONCLUSION}

Understanding the EU's law and practice in the negotiation and conclusion of FTAs is essential for the EU's negotiating partners, who have often been puzzled by its decision-making complexity (Devuyst, 2013). In this vein, the section provides an overview of the EU's inter-institutional and legal practice in the negotiation and conclusion of international trade agreements.

The EU pursues trade liberalization on three main axis: at multi- lateral level, within the WTO system, at unilateral level, through the GSP and at bilateral or regional level, through the conclusion of trade agreements with single or groups of third countries (EU Commission, 2006). More recently, renewed emphasis was placed on the importance of the regional dimension, promoting the conclusion of comprehensive bilateral/regional FTAs, which establish preferential free trade and investment "corridors" between the EU and its commercial partners (Cellerino, 2015), without -at the same time- denying the centrality of the multilateral system. The newly engineered FTAs are ideally based on reciprocity, comprehensive in scope and aim at the highest possible degree of liberalization in most economic sectors.

Article 216, paragraph 1, of the Treaty on the Functioning of the European Union (TFEU) and Article 37 of the Treaty on the European Union (TEU) confer the EU with the power to conclude treaties, together with the relevant norms on substantive competences. The decisions on the mandate to negotiate, on the signing and on the conclusion of the agreement are issued by the institution participated by representatives from each member State at ministerial level, the Council, according to Article 218 TFEU.

The role of European Parliament, which instead represents EU citizens, in this procedure was strengthened by the 2009 reform: the range of cases in which the consent of the European Parliament is required has been widened $^{12}$ and, in cases where consent is not necessary, the European Parliament must always be consulted. The only agreements that are con-

11 As will be further developed infra, only very few documents have been released thus preventing a scientific approach to the actual subject matters covered by the FTA.

12 Article 218, paragraph 6, subparagraph 2, lit. a, item v, TFEU. 
cluded without any obligatory participation of the European Parliament are those exclusively concerning the area of the Common Foreign and Security Policy ('CFSP'), whereas the rule according to which the European Parliament shall be immediately and fully informed at every stage of the procedure applies in all areas of EU law.

The European Parliament's opportunity to intervene on the negotiation drafts of agreements is nevertheless constrained by the fact that it is only requested an approval or rejection of the text, without the possibility to amend the draft, proposed by the Commission and embedded in the mandate issued by the Council. This did not prevent the Parliament from refusing to approve international agreements such the Anti-Counterfeiting Trade Agreement (Baroncini, 2013) nor from challenging measures adopted without its necessary involvement, considered as an 'essential procedural requirement' ${ }^{13}$.

The failure to comply with an essential procedural requirement is sufficient to subject the decision that concludes the treaty to annulment procedure ${ }^{14}$ and thus make the whole agreement void in the $\mathrm{EU}^{15}$. The same can be said with regard to the voting rule to be fol- lowed at Council level. In general, the Council adopts its decisions by qualified majority, upon the proposal of the negotiator, who is appointed by the Council itself. Unanimity is required if the agreement is an association ${ }^{16}$ or a cooperation ${ }^{17}$ one, or one with candidates for accession to the EU. Conversely, an FTA lies on the procedural basis of common commercial policy and thus requires the mere majority of Council members ${ }^{18}$. This contributes to explaining the preference for concluding an agreement on the trade, under the qualified majority rule before progressing toward the IAA, which instead requires unanimous consent among States' representatives at Council level.

According to this brief recap of how agreements are concluded, it is apparent that EU citizens' involvement in this activity is to some extent granted via the parliamentary scrutiny on the conclusion of international agreements. Nevertheless, as will be shown in section 4, civil society inclusion in international trade agenda is a rather edgy topic.

The EU can conclude agreements with one or more third countries or international organizations in a potentially extremely wide array of subject matters, having as a principal limit the principle of conferral ${ }^{19}$ and the divi-

\footnotetext{
13 ECJ Case C-658/11, European Parliament v Council of the European Union, [2014], ECLr:EU:C:2014:2025, par. 86.

14 Article 263 TFUE.

15 Article 264, paragraph 1, TFEU.

16 Article 217 TFEU.

17 Article 212 TFEU.

18 Article 207 TFEU.

19 The principle of conferral is a fundamental principle of European Union law. According to this principle, the EU
} is a union of member states, and all its competences are voluntarily conferred on it by its member states. The EU has 
sion of competence with member States ${ }^{20}$. The 2009 treaty reform qualifies the nature of common commercial policy (Bungenberg \& Herrmann, 2013) by listing it among the a priori exclusive competences of the Union. The TFuE clarifies the scope of such competence as including: tariff rates, the conclusion of agreements relating to trade in goods and services, the commercial aspects of intellectual property, foreign direct investment, the achievement of uniformity in measures of liberalization, export policy and measures to protect trade such as those to be taken in the event of dumping or subsidies (Koutrakos, 2008). Member States are therefore precluded from the exercise of external competences as regards international trade matters with the exception of the transport sector ${ }^{21}$.

Whenever a trade agreement also contains provisions belonging to competences shared between the EU and its members, it is concluded as a mixed agreement. In the case of agreements falling under the exclusive competence of the EU, the Council's decision so providing is sufficient to ensure the entry into force of the agreement, both in the EU's and member States' legal orders. Conversely, EU member States must conclude and implement the portions of mixed agreements falling under their own competence, in accordance with their relevant domestic procedures.

It is worth recalling that mixity -in the framework of agreements conclusion - is the most common situation; therefore, the number of cases in which the $\mathrm{EU}$ is alone on the negotiation table and, later, as a party to agreements, is relatively small. Mixity represents an element of complexity in EU's multilayered legal system that cannot be disregarded: on the one hand, it implies that agreements must be negotiated among 28 member States ${ }^{22}$, the EU and the international partner(s). On the

no competences by right, and thus any areas of policy not explicitly agreed in treaties by all member states remain the domain of the member states. It is spelled out fully in Articles 4 and 5 of the TEU.

20 These competences are divided into 3 main categories: exclusive competences; shared competences; and supporting competences. There are main types of competences. Exclusive competences (Article 3 TFEU) in which the EU alone is able to legislate and adopt binding acts. EU countries are able to do so themselves only if empowered by the EU to implement these acts. The EU have exclusive competence in the following areas: customs union; the establishing of competition rules necessary for the functioning of the internal market; monetary policy for euro area countries; conservation of marine biological resources under the common fisheries policy; common commercial policy; conclusion of international agreements under certain conditions. Shared competences (Article $4 \mathrm{TFEU}$ ): the EU and EU countries are able to legislate and adopt legally binding acts. EU countries exercise their own competence where the EU does not exercise, or has decided not to exercise, its own competence. Supporting competences (Article 6 of the TFEU): the $\mathrm{EU}$ can only intervene to support, coordinate or complement the action of EU countries. Legally binding EU acts must not require the harmonisation of EU countries' laws or regulations.

21 Article 207, par. 5 TfEeU.

22 Brexit seems to have little to no impact over the EU-Mercosur negotiations, as confirmed by Argentina's foreign minister who said that she believes "once the dust settles" from Brexit, the EU-Mercosur negotiations will "emerge stronger". Source: Euroefe.es (last visited 12 September 2017). Argentine Commerce Secretary Miguel Braun stated that "the UK is still part of the EU, and we are still negotiating with all the EU. Brexit would reduce the size of the 
other hand, it also means that, once adopted, the agreement needs to be implemented at domestic level in numerous legal orders, where different procedures exist for implementation of international agreements. This aspect will be developed in Section 4.

\section{MERCOSUR'S INSTITUTIONAL SETTING AND CONCLUSION OF INTERNATIONAL AGREEMENTS}

The Protocol of Ouro Preto gave Mercosur a legal personality under public international $\mathrm{law}^{23}$, with implications both internally and internationally ${ }^{24}$. The same Protocol also authorizes Mercosur to conclude headquarters agreements, as well as to negotiate and sign agreements with third States, groups of States and international organizations ${ }^{25}$.

A particular feature of Mercosur, despite it being an international organization, is that its founding member States did not transfer any part of their sovereignty to it. Consequently, its institutions have no supranational authority: Mercosur's institutions - Council of the Common Market, Common Market Group and Trade Commission - are of an intergovernmental nature ${ }^{26}$, as they are composed of representatives of each member and decisions must be taken by consensus. The negotiation and conclusion of treaties require the participation of all Mercosur members. Agreements entered into by Mercosur are not directly applicable in the territory of its members; they require ratification and implementation at the national level by each member: once a decision has been adopted, the members take the necessary measures to incorporate it into their domestic legislation. The constitutions of founding member States establish that constitutional provisions take precedence over international law-as treaties concluded by Mercosur are. As regards the relation between international law and domestic law, things are more complex: while the constitutions of Argentina and Paraguay expressly lay down the prevalence of international treaties, in Brazil and Uruguay the hierarchy is determined by the rules of lex posterior and lex specialis (Schmidt, 2014). Similarly to parts of the FTA falling under EU member States' competence, the agreement, once adopted, will undergo a complex implementation phase in all involved legal orders, under different procedures.

Among the common trade policies of Mercosur only the common external tariff, an exceptions list and a customs regime have been established so far. These factors might

market, there are some challenges to be addressed. At the same time we are open to discuss future potential trade deals with the UK". There seem to be some space for bilateral negotiations between Mercosur countries and the Uk, once the Brexit procedures will be completed.

23 Article 34, Protocol of Ouro Preto ('POP').

24 Article 35, POP

25 Article 8, IV, POP.

26 See Section 4.A. 
eventually jeopardize the prompt entry into force of the document and possibly discourage negotiators in the attempt of reaching a shared consensus on the draft. Nevertheless, in June 1996, Mercosur signed an FTA with Chile and Bolivia, in 2005 with Colombia and Ecuador and in 2006 with Peru, thereby enhancing the organization's expertise in drafting and implementation of FTAs. Mercosur also has a strategic interest in negotiations with the EU due to its own legitimation as a viable economic partner, due to the fact that the latter has been often questioned (Gomez Lehay, 2015).

Beside the mentioned decision-making bodies, three advisory bodies exist: i) the Secretariat; ii) the Socio-Economic forum and iii) the Parliament. With specific regard to the latter, at the Xxvir Meeting of Mercosur Heads of State in 2004, the Common Market Group instructed an ad hoc commission to write a protocol establishing a Parliament for Mercosur. In 2005, the presidents of Argentina, Brazil, Paraguay and Uruguay signed the Constitutive Protocol of the Mercosur Parliament ${ }^{27}$, creating the new body. The Parliament principal functions lie in the protection of democracy and human rights in the member States and in stimulating the integration process ${ }^{28}$. It should also develop opinions on draft standards requiring legislative approval by member States. With regard to domestic procedures for incorporation of Mercosur law, after the decisionmaking bodies adopted any regulation, the Parliament can only urge national authorities to adopt the necessary steps or to establish a preferential procedure for the treatment of Mercosur standards. However, decision-making bodies are not obliged to comply with the parliamentary opinion, being able to adopt the legislation without it being in conformity with parliamentary advice (Cabrol, 2011).

The following section develops some reflections on challenges that could hinder the agreement's conclusion, at first, and then its smooth implementation from the perspective of the institutional framework in which negotiations unfold.

\section{INSTITUTIONAL CHALLENGES}

After nearly ten years of EU-Mercosur negotiations, it should be possible to identify lessons to be learned and provide some hints for the negotiations to come. First, as emerges from previous

\footnotetext{
27 CMC/Dec n. 23/05.
}

28 Art. 4, par. 12 of the Protocol states that: "El Parlamento elaborará dictámenes sobre proyectos de normas del MERCOSUR que requieran aprobación legislativa en los Estados parte, en un plazo de noventa días (90). Estos proyectos son enviados al Parlamento por el órgano decisorio del mercosur, antes de su aprobación. Si el proyecto de norma es aprobado por el órgano decisorio, em concordância con el dictamen del Parlamento, la norma deberá ser remitida por cada Poder Ejecutivo nacional a su respectivo parlamento dentro del plazo de cuarenta y cinco (45) días. Si la norma no concuerda con el dictamen del Parlamento, o si no es expedida en el plazo requerido, ésta seguirá su trámite ordinario de incorporación. Los Parlamentos nacionales, según el cuerpo normativo de cada país, deberá adoptar las medidas necesarias para la instrumentación de las normas del MERCosur que hayan sido adoptadas em concordancia con el dictamen del Parlamento. El plazo máximo de duración del procedimiento preferencial será de hasta ciento ochenta (180) días corridos a partir del ingreso del proyecto de norma al Parlamento nacional”. 
Sections, a very wide number of actors currently participate in the FTA's making, whose strategic interests might collide. In the case of reaching the final stage, the agreement is deemed to be enacted by 5 plus 28 (27) States and the EU as such, with different constitutional procedures for the implementation of international law. The hyper-complexity of both the EU and Mercosur does not represent a benefit for the negotiations.

In retrospect, the failure to set a deadline for conclusion of negotiations, which arose from the EU's insistence on subordinating negotiations to the WTO negotiations, contributed to prolonging the process. In this regard, the participation of the EU in the legal framework deriving from the wTO agreements is particularly explanatory. When the Community was originally established, the General Agreement on Tariffs and Trade ('GATT') had been in place for about ten years. States today members of the EU were therefore bound by it when they concluded the Treaty of Rome establishing the European Economic Community and desired to observe the undertakings provided for by GaTT. Therefore, they made sure rights and obligations arising from agreements concluded before the entry into force of Treaty of Rome were not to be affected by the same Treaty ${ }^{29}$. At the same time, they sought the adherence of EU's objectives in the implementation of common commercial policy with the same aims and objectives as those pursued within the wTO agreements ${ }^{30}$. Today, all EU's

\footnotetext{
29 Today, art. 351 TfEu.

30 Today art. 206 TFEU.
}

members are also members to WTO, along with the EU itself who also has full member status.

Differently, Mercosur is not. In 1991 the Treaty of Asunción was ratified as part of the process of convergence towards a common external tariff, to which followed in 1995 the same States' individual membership to wTO. Thus, the interest in regional agreements occurs against a backdrop of increased membership and substantive participation in the work of the GATT and now the wTO.

The WTO agreements recognize that under some circumstances regional trading arrangements could hamper the trade interests of other countries. Normally, setting up a customs union or free trade area would violate the WTO's principle of equal treatment for all trading partners ("most-favoured-nation"), but GATT's Article XXIV allows regional trading arrangements to be set up as an exception, provided that special strict criteria are met. Article XXIV provides that when a free trade area or customs union is created, duties and other trade barriers have to be reduced or removed on substantially all sectors of trade in the group. Non-members should not find trade with the group any more restrictive than before the group was set up. Similarly, Article v of the General Agreement on Trade in Services ('GATS') provides for economic integration agreements in services. Other provisions in the WTO agreements allow developing countries to enter into regional or global agreements that include the reduction or elimination of tariffs and non-tariff barriers on trade among themselves. On 6 February 1996, 
the wTo General Council created the Regional Trade Agreements Committee. Its purpose is to examine regional groups and to assess whether they are consistent with wTO rules. The committee also examines how regional arrangements might affect the multilateral trading system, and what the relationship between regional and multilateral arrangements might be (World Trade Organization, 2016).

In the light of what above, the institutional setting in which the EU-Mercosur FTA unfolds is the following. Two international organizations, composed by States, are negotiating a trade agreement outside wто framework but under the supervision of the Regional Trade Agreements Committee of this very organization. All member States of both the EU and Mercosur are parties to wто, the EU is also a member but Mercosur is not. Nevertheless, its members' membership makes Mercosur bound, at least indirectly, to wто obligations and, possibly, constraints. Indeed, it is worth recalling that wто negotiations (the s.c. "Doha round") have been stuck since 2008. This could represent a boost to EU-Mercosur bilateral negotiations but, instead, the absence of a genuine consensus on the need for an FTA proved to be decisive in the failure of the first stage of EU-Mercosur negotiations (Robles, 2008). Simply put, the EU was protectionist in agriculture, while Mercosur was protectionist in foreign direct investment and in the manufacturing industry (Chaire Mercosur de Sciences Po, 2005). This can explain, on the Mercosur side, the growing influence of China and US in the region; on the contrary, the same influences add a sense of urgency on the EU side, due to the need to counteract them and secure preferential market access to EU's companies.

In this complex panorama, the paper chooses to highlight two challenges, considered as encompassing, or at least touching upon, the many institutional hinders that the EU and Mercosur face in the FTA negotiation process. Firstly, the non-State nature of both actors is highlighted, due to the added complexity it implies in reaching consensus among the parties and, secondly, the paper argues that increased participation of the agreement's recipients, i.e. citizens of the relevant States, could boost the process, which currently suffers from prolonged stagnation.

\section{Lack of statehood}

The institutional structure of both the EU and Mercosur might appear as one of the reasons why none of the desired agreements (the IAA and the FTA) has been concluded so far, and for the failure to reach today any binding draft of the negotiated texts.

Two fundamentally different approaches shaped both organizations' integration process, with different outcomes: neofunctionalism and intergovernmentalism. Neofunctionalism is based on the theory of functionalism, which refers to the shift of power to resolve problems from the sovereign States to international bodies (Chin Hong, 2010). Neofunctionalist ${ }^{31}$

31 Ibid. 
scholars also call for the development of official supranational organizations that acquire and exercise the partial sovereignty transferred by its member States. Intergovernmentalism provides that power in an international organization is possessed by member States and that decisions are unanimous. In other words, any exercise of power at a supranational level results from a direct decision by governments. The EU's acquis developed in the balance of the two principles, while Mercosur's present structure is explicitly intergovernmental, as no transfer of sovereignty has taken place. Thus, in combination with the presidential political system of its member States, Mercosur follows a strict model of top-down integration.

From an EU perspective, it has been previously highlighted that a Council mandate ${ }^{32}$ is necessary in order to begin negotiations and that the mandate itself is drafted in rather stringent terms, to which the negotiator must stick. Through the prism of intergovernmentalism, the pivotal role of member States' governments becomes evident. Given the rigid division of competences, another aspect of EU's 'way of FTAS' can be questioned: whether clauses on cultural, political or other types of noncommercial cooperation are included in trade agreements deliberately, in order to justify the participation of member States (Baratta, 2014).
States' interests in some sectors are safeguarded in the framework of an FTA also by way of different procedural requirements (unanimity vote) with reference to specific sectors such, for instance, intellectual property ${ }^{33}$. In this respect, the disparities generated by the different impact of the same agreement into the economies of single member States as well as in their legal orders, by means of different implementation processes, might create tension. This is particularly true with reference to Mercosur's States: despite its being an international organization, founding members did not transfer any part of their sovereignty to Mercosur institutions. Consequently, its institutions have no supranational authority. The Council of the Common Market, the Common Market Group and the Trade Commission are of an intergovernmental nature, as they are composed of representatives of each member and decisions are taken by consensus. Owing to the lack of supranational authority, the negotiation and conclusion of treaties require the participation of all members and each member State follows its own rules for ratification and incorporation of international law. In other words, agreements entered into by Mercosur are not directly applicable in its members' legal orders; they require approval or ratification at the national level by each State ${ }^{34}$.

\footnotetext{
32 Council Decision of 22 March 1999 concerning the conclusion, on behalf of the European Community, of the interregional framework cooperation agreement between the European Community and its Member States, of the one part, and the Southern Common Market and its Party States, of the other part. OJ L 112, 29.4.1999, p. 65-84.

33 Article 207, par. 4, TFEU.

34 More specifically, the Protocol of Ouro Preto states that "El Protocolo de Ouro Preto establece en el artículo 40 un procedimiento que consta de tres etapas para la aplicación interna de las normas: 1. Una vez aprobada la norma,
} 
This challenge regards EU's member States as well, with reference to treaties concluded under the 'mixity regime': the parts concluded in the exercise of EU's exclusive competences are directly applicable in EU's and member States' legal orders, absent any domestic activity of implementation, because they are considered as directly applicable ${ }^{35}$. Differently, the parts concluded by the member States in the exercise of their competence are to be subject to national implementation procedures. These procedures vary greatly in the today 28 member States and are likely to lead to different legal outcomes in the domestic legal orders.

Usually, an institutionalized framework of working groups and committees ensures implementation of FTAS concluded by the EU by monitoring their proper execution. In addition, a dispute settlement mechanism ('DSM') is usually provided for dealing with disputes among the parties. In the case of EU-Korea
$\mathrm{FTA}^{36}$, the latter has been considered the 'most substantial breakthrough' (EU Parliament, 2010) in the agreement.

DSMs are often inspired by the wTO dispute settlement model, providing for mandatory consultation, preference for mutually agreed solutions, possibility to resort to arbitral panels and an Appellate Body, temporary remedies in cases of noncompliance including the temporarily revert of most favored nation tariffs and arbitral review of compliance measures. Hearing of arbitration panels are open to public and submission of briefs by amicus curiae are possible. Under the EU-Korea FTA, social and environmental clauses are also subject to a panel arbitration, but the rulings are not binding in this case.

At the last EU-Mercosur negotiating round, the parties examined the issue of inserting a DSM in the framework of the FTA. The only disclosed document as this regard states as follows: "Discussions on DSM advanced at a

los Estados Partes adoptarán las medidas necesarias para su incorporación al ordenamiento jurídico nacional y comunicarán las mismas a la Secretaría Administrativa del Mercosur;

2. Cuando todos los Estados Partes hubieren informado la incorporación a sus respectivos ordenamientos jurídicos internos, la Secretaría Administrativa del Mercosur comunicará el hecho a cada Estado Parte;

3. Las normas entrarán en vigor simultáneamente en los Estados Partes 30 días después de la fecha de comunicación efectuada por la Secretaría Administrativa del Mercosur, en los términos del literal anterior. Con ese objetivo, los Estados Partes. Dentro del plazo mencionado, darán publicidad del inicio de la vigencia de las referidas normas, por intermedio de sus respectivos diarios oficiales". (art. 40).

35 Article 216, par. 1 TFUE states that 'Agreements concluded by the Union are binding upon the institutions of the Union and on its Member States'.

36 2011/265/EU: Council Decision of 16 September 2010 on the signing, on behalf of the European Union, and provisional application of the Free Trade Agreement between the European Union and its Member States, of the one part, and the Republic of Korea, of the other part Commission's statements. Free trade Agreement between the European Union and its Member States, of the one part, and the Republic of Korea, of the other part; Protocol concerning the definition of 'originating products' and methods of administrative cooperation; Protocol on mutual administrative assistance in customs matters; Protocol on cultural cooperation. OJ L 127, 14.5.2011, pp. 1-1426. 
considerable pace and the two sides came closer in a considerable number of issues. All aspects were covered at this round, and progress was made in the main text and the annexes (rules of procedure, code of conduct and mediation). The Code of Conduct is now agreed. A limited number of difficult issues remain open" 37 . It is obvious that the statement is, as such, not telling about actual intentions of the parties in this regard and, absent any substantial clue, one may question if the consensus on the topic has been reached at all so far. Alternatively, it is also possible to imagine that the released document is deliberately silent on the DSM's nature and purpose, due to the major critiques that the same mechanism received with reference to other FTAS.

\section{Lack of transparency and scarcity of civil society involvement}

Foreign affairs are inherently characterized by a democratic deficit, due to their very nature and the magnitude of involved interests, often relating to matters of State security. Therefore, the limited involvement of institutions usually pivotal in law making, such Parliaments, comes as no surprise. This is even more true vis a vis international organizations who are by definition participated by representatives of States as such. Furthermore, FTAs endorse interests that even if deemed to relapse (positively or negatively) on civil society are separated from citizens by so many institutional layers that their participation cannot be other that scarce.

In EU's experience, TTIP negotiations${ }^{38}$ showed that there is an ongoing quest for people's involvement, also in treaty-making: a petition to the Ombudsperson ${ }^{39}$ was successfully filed to the purpose of having the relevant drafts and document disclosed. Due to the lack of other case studies, the release of several documents in TTIP case cannot be regarded as a game changer. With regard to the EU-Mercosur's FTA, negotiations are not at a substantial stage and not binding commitments are in place among the parties yet.

Movements who oppose the conclusion of the agreement are numerous in both regions, though. Their main critiques revolve around the consequence of liberalization, on the agricultural industry in the $\mathrm{EU}^{40}$ and on

37 Report from the Xxvinth round of negotiations Of the Trade Part of the Association Agreement between the European Union and Mercosur Brussels, 3-7 July 2017. The previous report on the meeting that had took place between 10 and 14 October 2016 stated "The Parties discussed the consolidated text on Dispute Settlement, including proposals for changes to update the text in light of recent FTAs. Discussions covered most provisions including on complicated issues such as open hearings and cross-retaliation in order to identify areas of potential convergence. Further discussions will take place on issues such as amicus briefs, mediation and nullification and impairment”.

38 Transatlantic Trade and Investment Partnership, negotiated between the EU and the US.

39 Decision of the European Ombudsman closing the inquiry into complaint 119/2015/PHP on the European Commission's handling of a request for public access to documents related to TTIP. Opened on 18 Feb 2015 - Decision on 04 Nov 2015.

40 For agricultural products, there is considerable imbalance in the trade flows between the two regional blocs. From an EU perspective, there is a negative trade balance with Mercosur for agricultural products of roughly $€ 7.8$ billion. 
the manufacturing sector in Mercosur region (Robles, 2008): the economic efficiency of the FTA in both parties' systems is perhaps shadowed by its political discomfort. As highlighted previously, the institutional apparatus in which negotiations unfold is extremely complex and comprises many stakeholders, whose thick consensus (Pauwelyn, Wessel \& Wouters, 2012) largely over weights civil society's mobilization.

From an EU perspective, the increased participation of the Parliament in treaty making offers to persons (legal, natural or groups) an opportunity to get indirectly involved in the decision-making process, through the representation of their own interests. They can also participate in the Commission's activities in the early preparatory phase of discussion about launching trade negotiations, when the Commission holds public consultations with civil society. From a Mercosur's one, the Protocol of Ouro Preto introduced the possibility of private parties to submit complaints to the Trade Commission. The Commission considers complaints whenever the cause of the complaint concerns a matter within its competence. The Commission's mandate is to monitor the application of the common trade policy instruments and this can represent an expost monitoring instruments. Some authors pointed out that, with the limited role granted to the Parliament and its lack of decisionmaking powers, it is clear that MERCOSUR's in- stitutional system "debe ser interpretado como defensor del interés de los países signatarios por mantener una amplia libertad de acción y sin someterse a una injerencia por encima de las esferas gubernamentales" (Ensinck, 2008). In the light of this, one may assess a limited involvement of citizens in the process of drafting the FTA and this ultimately might lead to opposition toward its enactment in fact.

Obviously, both parties' nationals have also the opportunity for lobbying and/or the entitlement to legal protection provided for under their national laws.

With specific reference to DSMs mechanisms, they might have different natures. The solution provided for in TTIP was subject to severe criticisms, mostly relating to the issue of having foreign investors challenging national regulations before a panel, which was not appointed by a democratically-legitimate and transparent procedure. EU-Mercosur FTA, instead, does not include rebus sic stantibus any provision relating to investment but focuses on market access and removal of technical barriers to trade: earlier exchanged proposals mentioned such a chapter but when negotiation was resorted after the long pause, the issue is no longer considered by documents accessible to the public. Conversely, trade has been subject to multilateral rules negotiated and implemented within the auspices of wTO and backed up by the mentioned dispute settlement system.

It currently provides a market for $1.7 \%$ of EU agricultural exports, while $16 \%$ of EU agricultural imports stem from the Mercosur group. See A. Schneider, The EU-Mercosur Free Trade Agreement The Implications for Trade in Agriculture, Ceps Policy Brief, 107/June 2006. 
Nevertheless, it seems that EU decisionmakers and negotiators are aware of the sensitive nature of the topic, because in the only disclosed factsheet relating to the possible incorporation of DSM in EU-Mercosur FTA reveals the intention to including proposals for changes to update the text in light of recent FTAs'.

The reference is very likely to the TTIP saga but, in this case, due to the different object of the treaty, it is possible to question the necessity of such a proviso. The EU and Mercosur's countries would not lose the possibility to have disputes arising out the interpretation and/ or application of their FTA settled by ordinary means available under wтo law. Of course, WTO system does not go without criticism as well but, from a strategic perspective, the dereliction of DSM proviso in the negotiation agenda could help in smoothing at least some of the opponents' arguments.

Finally, from an EU perspective, other remedies ${ }^{41}$ are available for enforcement of trade agreements with third States and in this sense, the necessity of negotiating a complex and somehow uneasy DSM might lose momentum.

\section{CONCLUSION}

The paper suggests that an EU-Mercosur agreement could bring benefits for both the
EU and Mercosur in terms of economic growth $^{42}$. However, it also highlights a number of concerns, which have been examined through the prisms of institutional setting of both actors and scarcity of civil society involvement, in relation to the agreement's potentially significant adverse impact on both actors' most sensitive industries. The paper also notes that, while beneficial spillovers could be expected in many different fields, only a balanced and ambitious agreement, taking into account economic, social and environmental impacts, has the potential to bring maximum benefits to both partners and be conducive to sustainable development.

From the perspective of the two bloc's nature and institutional settings, two shortcomings have been identified: on the one hand, the hypercomplexity of decision-making and the necessary presence of a multitude of governmental actors make the negotiations particularly time and effort consuming. On the other hand, in order to have an efficient agreement in place, especially one implying major societal reforms in different sectors, it is advisable that stakeholders from civil society are properly involved in early stages of negotiations. While these assumptions might seem to contrast one to another. Conversely they are of mutual support: in this vein, the shift from a governmental-based approach towards a more

\footnotetext{
41 Regulation (EU) No 654/2014 of the European Parliament and of the Council of 15 May 2014 concerning the exercise of the Union's rights for the application and enforcement of international trade rules and amending Council Regulation (EC) No 3286/94 laying down Community procedures in the field of the common commercial policy in order to ensure the exercise of the Community's rights under international trade rules, in particular those established under the auspices of the World Trade Organization. OJ L 189, 27 June 2014.

42 For economic analysis and related figures, refer to A. Burrell, E. Ferrari, A. González Mellado, M. Himics, J. Michalek, S. Shrestha and B. Van Doorslaer, Potential EU-Mercosur Free Trade Agreement: Impact Assessment, 2011, available at http://ipts.jrc.ec.europa.eu/.
} 
democratically legitimate process might be the key for concluding a mutually beneficial trade instrument.

\section{REFERENCES}

Baratta, R. (2014). Sugli accordi misti: spunti di prassi recente, in AA.VV., Scritti in onore di Giuseppe Tesauro (pp. 1357-1381), Napoli.

Bungenberg, M. and Herrmann, C. (eds.) (2003). Common Commercial Policy after Lisbon. The Hague.

Cabrol C. (2011). El Parlamento del Mercosur: su limitado rol en el marco de una estructura institucional intergubernamental. Lupa Empresarial, 14. Available at http://www.ceipa.edu.co.

Cellerino, C. (2015). EU common commercial policy in context: opportunities and challenges of a changing landscape. Diritto del commercio internationale, 3, 783-807.

Chaire Mercosur de Sciences Po (2005). Annual report 2005. Available at http://www19.iadb.org.

Chin Hong, D. (2010). The EU Model for a TaiwanChina Free Trade Agreement. Chinese (Taiwan) Yearbook of International Law and Affairs, 26, 35-55.

De Wet, E. (2006). The emergence of international and regional value systems as manifestation of the emerging international constitutional legal order. Leiden Journal of International Law, 19, 611-632.

Devuyst, Y. (2013). European Union Law and Practice in the Negotiation and Conclusion of International Trade Agreements. Journal of International Business and Law, XII, 259-316.

Ensinck, O. (2008). La integración regional: los desafíos institucionales del mercosur, in Graglia, E. (eds.), Politicas municipales para el desarrollo local y regional II. Córdoba: Universidad Católica de Córdoba.
EU Commission (2006). Global Europe: competing in the world, $\operatorname{COM}(2006) 567$. Available at http:// eur-lex.europa.eu.

EU Commission (2015). Trade for all. Towards a more responsible trade and investment policy. Available at http://trade.ec.europa.eu.

EU Commission (2017), Report from the xxviIIth round of negotiations Of the Trade Part of the Association Agreement between the European Union and Mercosur Brussels, 3-7 July 2017. Available at http://trade.ec.europa.eu.

Gomez Lehay, P. (2015). The interregional association agreement between the European Union and Mercosur: is the timing right? (Bruges Political Research Papers 46/2015). Available at https:// www.coleurope.eu.

Hinojosa, L. (2009). EU-Mercosur Trade Agreement: Potential impacts on rural livelihoods and gender (with focus on bio-fuels feedstock expansion). Sustainability, 1, 1120-1143.

Koutrakos P. (2008). Legal basis and delimitation of competencies, in Cremona, M. and De Witte, B. (eds.), EU Foreign Relations Law, Constitutional Fundamentals (pp. 171-98). Oxford: Oxford University Press.

Pauwelyn, J., Wessel, R. A. and Wouters, J. (2012). When Structures Become Shackles: Stagnation and Dynamics in International Lawmaking (KU Leuven Working Paper 97). Available at http:// www.ejil.org.

Robles Jr, A. C. (2008). EU fTA Negotiations with SADC and Mercosur: integration into the world economy or market access for EU firms? Third World Quarterly, 29, 187-191.

Robles Jr., A. C. (2008). The EU and ASEAN: Learning from the Failed EU-Mercosur FTA Negotiations ASEAN. Economic Bulletin, 7, 334-344.

Schmidt, J. P. (2014). Mercosur. Max Plank Encyclopedia of international law, VII, 110-117. 